\title{
EFFECT OF LACTIC ACID BACTERIA ON EXTENTION OF SHELF LIFE AND GROWTH OF LISTERIA MONOCYTOGENES IN BEEF STEAKS STORED IN CO -RICH ATMOSPHERE
}

\author{
Djamel Djenane ${ }^{1,2 *}$; Luis Martínez²; Domingo Blanco²; Javier Yangüela²; José A. Beltrán²; Pedro Roncalés ${ }^{2}$
}

${ }^{1}$ Université Mouloud Maameri, Faculté des Sciences Biologiques et des Sciences Agronomiques, Département de Biochimie et de Microbiologie, Complexe Hasnaoua, Tizi-Ouzou, Algérie; ${ }^{2}$ Department of Animal Production and Food Science, Laboratories of Food Technology and Food Hygiene, Faculty of Veterinary Science, University of Zaragoza, Zaragoza, Spain

Submitted: September 30, 2004; Returned to authors for corrections: August 02, 2005; Approved: November 17, 2005

\begin{abstract}
Beef steaks were inoculated with one or other of two protective strains of lactic acid bacteria (bacteriocinogenic Lactobacillus sakei CTC 372 or the uncharacterized Lactobacillus CTC 711), and stored under modified atmospheres (20-40\% $\mathrm{CO}_{2}$ ). Inoculation of meat with LAB inhibited growth of the spoilage bacteria. Neither $\mathrm{CO}_{2}$ in the pack atmosphere or inoculation with protective strains, nor a combination of both, affected formation of metmyoglobin or the development of off-odours. The formation of metmyoglobin in meat pigments and the sensory odour scores were compatible to those of fresh meat which had not undergone either oxidative deterioration or microbial spoilage. Listeria monocytogenes was inhibited in broth by meat surface microbiota containing the protective strains. With initial numbers of $5.6 \log \mathrm{cfu} \mathrm{mL}^{-1}$, after 7 days incubation at $3^{\circ} \mathrm{C}$, L. monocytogenes were recovered at $\log$ mean numbers of $2.8 \log \mathrm{cfu} \mathrm{mL}^{-1}$ when no protective strain was present. At $8^{\circ} \mathrm{C}$, the numbers of $L$. monocytogenes were reduced by about 2.5 or $1.5 \log \mathrm{mL}^{-1}$ in the presence of $L b$. sakei CTC 372 or $L b$. CTC 711, respectively. At $25^{\circ} \mathrm{C}$, the numbers of $L$. monocytogenes recovered from broth containing either protective strain were about $5 \log$ lower than the numbers recovered from broth containing L. monocytogenes only.
\end{abstract}

Key words: fresh meat, modified atmosphere, preservation, lactic acid bacteria, spoilage, Listeria monocytogenes

\section{INTRODUCTION}

Meat is a very perishable food. Both oxidative and microbial processes are involved in meat deterioration. The potential for psychrotrophic spoilage microorganisms to grow during the extended refrigerated storage period and decrease organoleptic quality or spoil the food product is also a concern. With sufficient time at refrigeration temperatures, several types of psychrotrophic bacteria may grow to levels that may cause meat spoilage. These microorganisms include Brochothrix thermosphacta (B. thermosphacta), lactic acid bacteria (LAB), and Pseudomonas spp. (38). B. thermosphacta, which is aerobic to facultatively anaerobic, has been recovered from packaged beef, pork and lamb. Spoilage may involve development of sliminess and production of off-odors and off-flavors conferred by short chain fatty acids (32).

Pseudomonas spp., which are aerobic, are among the most common spoilage agents of refrigerated foods (19). Growth of Pseudomonas spp. and other Gram-negative psychrotrophs is affected by oxygen tension and other factors. During growth, pseudomonads produce proteases and lipases that can catalyze reactions causing degradation of protein and fat. The consequence of these reactions is formation of peptides and fatty acids of undesirable flavor and odor. Sometimes these bacteria also produce unsightly green pigments (38).

Oxygen $\left(\mathrm{O}_{2}\right)$ concentrations of $60-80 \%$ are used in modified atmosphere packaging (MAP) to maintain myoglobin $(\mathrm{Mb})$ in its oxygenated form $\left(\mathrm{MbO}_{2}\right)$. High $\mathrm{O}_{2}$ concentration retards

*Corresponding Author. Mailing address: Université Mouloud Maameri. Faculté des Sciences Biologiques et des Sciences Agronomiques. Départment de Biochemie et de Microbiologie. Complexe Hasnaoua, Tizi-Ouzou, 15000. Algérie. E-mail: djenane@unizar.es 
metmyoglobin (MetMb) formation at meat surfaces and does not accelerate growth of aerobic organisms $(13,37,43)$. If pathogens are present they may grow and the meat may become hazardous for consumers. A major concern associated with packaging fresh meat under modified atmospheres (MA) is the risk of growth of psychrotrophic pathogens such as Listeria monocytogenes $(18,27)$. L. monocytogenes is a mesophilic foodborne pathogen, which shows psychrotrophic behaviour. It is widely distributed in nature and its control in food is difficult due to the relatively high tolerance to inhibitory conditions when compared to other food borne pathogens (16). Growth of L. monocytogenes in meat packaged under MA has been the focus of many studies, but the effect of carbon dioxide $\left(\mathrm{CO}_{2}\right)$ on the growth of $L$. monocytogenes is not clear, while the effect of including $\mathrm{O}_{2}$ in the atmosphere is also uncertain (51). Inhibition of $L$. monocytogenes in meats cannot be achieved by MA alone (27).

Some strains of LAB are antagonistic against many microorganisms, including spoilage and pathogenic bacteria, because they produce bacteriocins $(1,3,31)$. It has been suggested that bacteriocin-producing LAB might be useful as natural preservatives to enhance meat shelf life and safety by inhibiting spoilage and pathogenic bacteria $(5,6)$. Inhibition of spoilage of fresh meat by bacteriocinogenic Lactobacillus sakei (Lb. sakei) CTC 494 (sakacin K-producing) together with MAP has been reported (26). Aymerich et al. (4) characterized $L b$. sakei CTC 372 as a sakacin T producing strain; they also demonstrated that it can strongly inhibit L. monocytogenes and Staphylococcus aureus (S. aureus). LAB CTC 711 has not been characterized for bacteriocin production. However, according to Hugas (personal communication) it inhibited not only $L$. monocytogenes and S. aureus but also Gram-negative bacteria, such as Salmonella and Escherichia coli. The effects of bacteriocin-producing LAB on pathogens in meat may be difficult to evaluate because intrinsic factors of the product can influence the activity of bacteriocins $(11,28,49)$. The inhibitory effects of $\mathrm{LAB}$ on L. monocytogenes might then be more reality discussed in broth cultures than with meat $(8,41,45)$.

The aims of this study were to examine the effects of two protective $\mathrm{LAB}$ inoculated onto meat on the preservation of the quality characteristics of beef steaks stored under $\mathrm{CO}_{2}$-rich atmospheres and to test the effects of the LAB against $L$. monocytogenes in broth at various temperatures.

\section{MATERIALS AND METHODS}

\section{Meat samples}

The Longissimus dorsi (LD) muscle from a single beef carcass was obtained at $48 \mathrm{~h}$ post-mortem ( $\mathrm{pH}$ 5.6-5.7), and trimmed of external fat. Forty-five steaks, each $1.5 \mathrm{~cm}$ thick and weighting about $150 \mathrm{~g}$, were aseptically cut and divided into halves. The steak portions were exposed to air for about $1 \mathrm{~h}$ at $1^{\circ} \mathrm{C}$ to allow for blooming.

\section{Bacterial cultivation and media}

The strains of LAB used, bacteriocinogenic Lb. sakei CTC 372 and the uncharacterized $L b$. CTC 711, were isolated from meat or meat products $(4,25)$ and kindly provided by Dr. M. Hugas (Centro de Tecnología de la Carne, IRTA, Monells, Spain). They were grown on Man, Rogosa and Sharpe (MRS) agar (Merck; Darmstadt, Germany) at $30^{\circ} \mathrm{C}$.

The indicator strain of L. monocytogenes used in this study was from the Spanish Type Culture Collection (STCC 4031, corresponding to ATCC 15313; Valencia, Spain) and was kindly provided by Prof. Dr. Sala (University of Zaragoza, Spain). L. monocytogenes was grown in Tryptic Soy Broth (TSB; Biolife, S.r.l. Milano, Italy) supplemented with $0.6 \%$ yeast extract (YE; Biolife) and maintained on slants of Tryptic Soy Agar (TSA; Biolife) supplemented with $0.6 \%$ of yeast extract. The inoculum was prepared by transferring one colony of L. monocytogenes from a plate to a test tube containing $5 \mathrm{~mL}$ of sterile supplemented TSB (TSB-YE). After inoculation, the tube was incubated at 36 $\pm 1^{\circ} \mathrm{C}$ for $24 \mathrm{~h}$. Erlenmeyer flasks $(250 \mathrm{~mL})$ containing $50 \mathrm{~mL}$ of TSB-YE were inoculated with this culture to obtain approximately $10^{6}$ cells $\mathrm{mL}^{-1}$.

To prepare inocula of $\mathrm{LAB}$, an isolated colony of each strain was transferred from MRS agar into a test tube containing $10 \mathrm{~mL}$ of sterile MRS broth (Merck; Darmstadt, Germany), which were incubated overnight at $30^{\circ} \mathrm{C}$ to obtain a culture containing approximately $10^{6} \mathrm{cfu} \mathrm{mL}^{-1}$. When necessary, the culture was diluted with MRS broth to obtain the required cell numbers. Stock cultures of $\mathrm{LAB}$ strains were maintained as frozen stocks at $-80^{\circ} \mathrm{C}$ in $20 \%$ (vol/vol) sterile glycerol (Panreac, Barcelona. Spain).

\section{Inoculation of meat with LAB strains}

After blooming, the 90 portions of meat were divided into three groups of 30. One group was sprayed with a culture of $L b$. sakei CTC 372 to achieve $10^{4}-10^{5} \mathrm{~cm}^{-2}$. The second group was similary sprayed with a culture of LAB CTC 711. The final group of steaks was sprayed with sterile $0.1 \%$ peptone water. Uniform spraying of the surface of beef steaks was achieved using a spray gun. To ensure that the inoculum was evenly distributed on meat surfaces, steaks were selected at random for determination of numbers of LAB.

\section{Packaging and storage}

Each meat portion was placed on an expanded polystyrene tray $(15.5 \times 21.5 \times 2.5 \mathrm{~cm})$. Each tray was placed into a polyethylene and polyamide (PE/PA, 80/20 $\mu \mathrm{m}$ thickness) laminate pouch (Sidlaw Packaging-Soplaril, Barcelona, Spain) with a water vapour permeability of $5-7 \mathrm{~g} \mathrm{~m}^{-2} 24 \mathrm{~h}^{-1}$ at $23^{\circ} \mathrm{C}$ and oxygen permeability of $40-50 \mathrm{~mL} \mathrm{~m}^{-2} 24 \mathrm{~h}^{-1} \mathrm{~atm}^{-1}$ at $23^{\circ} \mathrm{C}$. For pouches containing steaks subjected to the same treatment, 15 were filled with $1.5 \mathrm{~L}$ of $70 \%$ $\mathrm{O}_{2} / 20 \% \mathrm{CO}_{2} / 10 \% \mathrm{~N}_{2}$ (Abelló Linde S.A.; Barcelona, Spain), and the other 15 with $1.5 \mathrm{~L}$ of $60 \% \mathrm{O}_{2} / 40 \% \mathrm{CO}_{2}$ (Abelló Linde S.A.). The pouches were heat sealed, and stored in the dark at $1 \pm 1^{\circ} \mathrm{C}$. 
On days 7, 12, 17, 22 and 28 of storage, 3 packs from each treatment group with each atmosphere were opened. One steak from each set of three was used for microbial sampling, while the other two were used for sensory analysis and for instrumental and chemical analyses.

\section{Inhibitory effect on L. monocytogenes}

An overnight culture of L. monocytogenes was suspended in TSB-YE, prepared with $50 \mathrm{mM}$ sodium phosphate buffer, $\mathrm{pH}$ 5.6-5.7, to simulate the normal $\mathrm{pH}$ of meat. Cultures of $\mathrm{Lb}$. sakei CTC 372 and $L b$. CTC 711 were obtained from inoculated meat on day 7 of storage by swabbing $10 \mathrm{~cm}^{2}$ of meat surfaces with a sterile cottonwool swab. Swabs were stirred in $10 \mathrm{~mL}$ of $0.1 \%$ peptone water. One $\mathrm{mL}$ of each suspension was added to each of 4 test tubes containing $10 \mathrm{~mL}$ of the suspension of $L$. monocytogenes. The broth containing $\mathrm{LAB}$ and $L$. monocytogenes was incubated for up to 10 days at 3,8 or $25^{\circ} \mathrm{C}$. To prepare the control samples, uninoculated beef steaks were swabbed on day 7 of storage and cultures containing LAB and L. monocytogenes were prepared and incubated as before.

\section{pH measurements}

The meat $\mathrm{pH}$ was measured after homogenisation of $5 \mathrm{~g}$ of meat in distilled water, using a Micro pH $2001 \mathrm{pH}$ meter (CRISON mod.) with an INGOLD type U 402 electrode. Three readings were obtained for each steak portion.

\section{Microbiological analysis}

Two sterile cottonwool swabs moistened with $0.1 \%$ peptone water were used to swab $10 \mathrm{~cm}^{2}$ of meat surface delimited by a sterile, stainless steel template. Swabs were stirred in $10 \mathrm{~mL}$ of $0.1 \%$ peptone water. Serial ten-fold dilutions were prepared by diluting $1 \mathrm{~mL}$ in $9 \mathrm{~mL}$ of $0.1 \%$ peptone water. Three plates were prepared from each dilution by pouring 1 $\mathrm{mL}$ into the fluid agar appropriate for each microbial species. LAB were enumerated in plates of MRS agar, which were incubated anaerobically at $30^{\circ} \mathrm{C}$ for $48-72 \mathrm{~h}$. B. thermosphacta were enumerated in plates of streptomycin thallous acetate actidione (STAA) agar (Biolife s.r.l; Milano, Italy), which were incubated aerobically at $25^{\circ} \mathrm{C}$ for $72 \mathrm{~h}$. Pseudomonas spp. were enumerated in plates of cephaloridine fucidin cetrimide (CFC) agar (Oxoid; Basingstoke, England), incubated at $25^{\circ} \mathrm{C}$ for 48 $72 \mathrm{~h}$ (30). L. monocytogenes was enumerated in plates of PALCAM agar (Merck; Darmstadt, Germany), incubated aerobically at $36 \pm 1^{\circ} \mathrm{C}$ for 24 to $48 \mathrm{~h}$. The logs of mean values for the counts from plates were recorded.

\section{Colour determination}

Meat surface colour was measured using a reflectance spectrophotometer (CM-2002, Minolta, Osaka, Japan) $30 \mathrm{~min}$ after package opening, to allow for colour stabilisation after exposure to air. CIE L*, a*, b* values (9) were recorded. Hue- angle $(\mathrm{h})$ and Chroma $\left(\mathrm{C}^{*}\right)$ were calculated using the formulae: $\mathrm{h}=\tan ^{-1}\left(\mathrm{~b}^{*} / \mathrm{a}^{*}\right)$ and $\mathrm{C}^{*}=\left(\mathrm{a}^{* 2}+\mathrm{b}^{* 2}\right)^{1 / 2}$, respectively.

\section{Metmyoglobin analysis}

The MetMb percentage of the total myoglobin perceptible at the steak surface was estimated spectrophotometrically, by the method of Stewart et al. (48), with measurement of steak surface reflectance at 525 and $572 \mathrm{~nm}$ (Minolta CM-2002; Osaka, Japan). The maximum value of the ratios of $(\mathrm{K} / \mathrm{S})_{572 \mathrm{~nm}}$ to $(\mathrm{K} / \mathrm{S})_{525 \mathrm{~nm}}$ at the beginning of the experiment was fixed as $0 \%$ $\mathrm{MetMb} ; \mathrm{K}$ and $\mathrm{S}$ were the absorption and the scattering coefficients, respectively, and K/S ratios were calculated from reflectivity $\left(\mathrm{R}_{\infty}\right)$ values using the Kubelka-Munk equation [K/ $\left.S=\left(1-R_{\infty}\right)^{2} / 2 R_{\infty}\right]$. The value of $100 \%$ MetMb was obtained following the same procedure after oxidising a sample of meat in a $1 \%(\mathrm{w} / \mathrm{v})$ solution of potassium ferricyanide (35). The average value for each steak was the mean of 20-25 determinations.

\section{Lipid oxidation}

Lipid oxidation was assessed in triplicate by the 2thiobarbituric acid (TBA) method of Pfalzgraf et al. (40). Thiobarbituric acid reactive substances (TBARS) values were calculated from a standard curve of malonaldehyde (MA) and expressed as mg MA kg${ }^{-1}$ meat.

\section{Sensory evaluation}

Meat samples were evaluated for off-odour by a six-member panel, trained according to the method of Cross et al. (10). For rating odour, meat samples presenting different off-odour characteristics within the range of the evaluation scale were used. Samples used for rating included packaged beef steaks that were either fresh or stored at $4^{\circ} \mathrm{C}$ for up to 3 weeks.

In all assessments, beef steaks were evaluated 20 min after pack opening. Two samples for each treatment and time were taken, identified with 3-digit random numbers and placed in polystyrene trays of $15.5 \mathrm{~cm}$ x $21.5 \mathrm{~cm}$. Each panelist received two half steak portions from each treatment, randomly numbered and served. The samples for evaluation were presented at room temperature of about $25^{\circ} \mathrm{C}$.

The attribute off-odour was rated using a 5-point descriptive scale, in which: 1 = no off-odour, 2 = slight off-odour, $3=$ little offodour, $4=$ moderate off-odour, and $5=$ strong off-odour (12).

\section{Analysis of data}

The significance of differences amongst treatments after each day of storage was determined by analysis of variance using the Least Square Difference (LSD) method of the General Linear Model procedure of Statistical Package for Social Sciences (SPSS) program for Windows, version 6.1.2 (47). All other calculations were performed using Microsoft Excel, version 5, statistical functions (Microsoft Corp., Redmond, WA, USA). Differences were considered significant at the $\mathrm{P}<0.05$ level. 


\section{RESULTS}

Few presumptive Pseudomonas spp. were recovered from steaks after 12 days of storage (Fig. 1). The numbers of Pseudomonas spp. recovered from uninoculated steaks packaged in the $40 \% \mathrm{CO}_{2}$ atmosphere were $0.8 \log$ unit lower than the numbers recovered from uninoculated steaks packaged in $20 \% \mathrm{CO}_{2}$ atmosphere after 17 days of storage. However, after 22 days of storage, the numbers recovered from uninoculated steaks packaged under either atmosphere were not significantly different $(\mathrm{P}>0.05)$.

Initial numbers of LAB were less than $10 \mathrm{cfu} \mathrm{cm}^{-2}$ on uninoculated steaks (result not shown). The inoculated steaks all carried LAB at 4 to $5 \log \mathrm{cfu} \mathrm{cm}^{-2}$. After inoculation with $L b$. sakei CTC 372, the numbers of Pseudomonas spp. recovered from steaks were about $1 \log$ unit lower than the numbers recovered from uninoculated steaks after 28 days of storage under both $\mathrm{CO}_{2}$ atmospheres. However, the numbers recovered from steaks inoculated with $L b$. CTC 711 were about $1 \log$ unit lower than the numbers recovered from uninoculated steaks throughout storage, when steaks were packaged under $20 \%$ $\mathrm{CO}_{2}$. Presumptive $B$. thermosphacta reached maximum values of about $5 \log \mathrm{cfu} \mathrm{cm}^{-2}$ at the end of storage (Fig. 2). The log numbers recovered from uninoculated steaks were similar during 22 days of storage; but the numbers recovered from steaks packaged under $40 \% \mathrm{CO}_{2}$ were about $1 \log$ unit lower than the numbers recovered from steaks packaged under $20 \% \mathrm{CO}_{2}$ after 28 days of storage. The numbers of $B$. thermosphacta recovered from steaks inoculated with $\mathrm{Lb}$. sakei CTC 372 were about $2 \mathrm{log}$ units lower than the numbers recovered from uninoculated steaks after 28 days of storage under either $\mathrm{CO}_{2}$ atmosphere. The numbers recovered from steaks inoculated with $L b$. CTC 711 were about $1 \log$ unit lower than the numbers recovered from uninoculated steaks throughout storage when steaks were packaged under $20 \% \mathrm{CO}_{2}$.

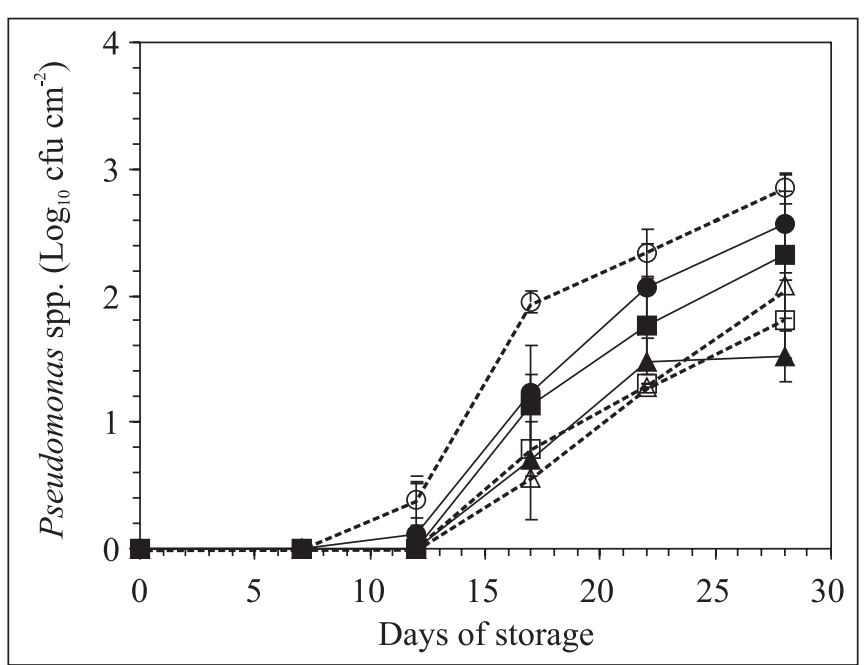

Figure 1. Numbers of Pseudomonas spp. recovered from beef steaks stored at $1 \pm 1^{\circ} \mathrm{C}$ under atmospheres of $70 \% \mathrm{O}_{2} / 20 \% \mathrm{CO}_{2} /$ $10 \% \mathrm{~N}_{2}$ (open symbols) or $60 \% \mathrm{O}_{2} / 40 \% \mathrm{CO}_{2}$ (closed symbols) without being inoculated (circles) or after being inoculated with Lactobacillus sakei CTC 372 (triangles) or Lactobacillus CTC 711 (squares).

Neither high $\mathrm{CO}_{2}$ concentrations, nor inoculation with $\mathrm{LAB}$ protective strains appeared to affect MetMb formation (Fig. 3). The results of the CIE indices of redness (CIE $\mathrm{a}^{*}$, hue and Chroma; data not shown) agreed with those for MetMb formation. The $\mathrm{pH}$ values of steaks did not differ significantly $(\mathrm{P}>0.05)$ during storage (data not shown).

Table 1 shows the sensory off-odour scores for beef steaks during storage. Neither variation in $\mathrm{CO}_{2}$ concentration, nor inoculation with the protective $\mathrm{LAB}$ strains affected the odour of the meat.

Table 1. Sensory panel scores (mean \pm SD) for off odours of beef steaks packaged under atmospheres containing 20 or $40 \% \mathrm{CO}_{2}$ without or after being inoculated with lactic acid bacteria, after storage at $1 \pm 1^{\circ} \mathrm{C}$ for various times.

\begin{tabular}{|c|c|c|c|c|c|c|c|c|}
\hline \multirow[b]{2}{*}{ Off-odour* } & \multicolumn{2}{|c|}{ Treatments } & \multicolumn{6}{|c|}{ Days of storage } \\
\hline & $\mathrm{CO}_{2} \%$ & Inoculum & $\mathbf{0}$ & 7 & 12 & 17 & 22 & 28 \\
\hline & 20 & None & $1 \pm 0.0$ & $1 \pm 0.0$ & $1.3 \pm 0.4^{x}$ & $2.5 \pm 0.3^{\mathrm{x}}$ & $3.6 \pm 0.2^{x}$ & $4.8 \pm 0.3^{y}$ \\
\hline & 20 & LAB $1^{\text {a }}$ & $1 \pm 0.0$ & $1 \pm 0.0$ & $1.0 \pm 0.0^{\mathrm{x}}$ & $2.3 \pm 0.6^{x}$ & $3.3 \pm 0.4^{x}$ & $4.3 \pm 0.2^{x}$ \\
\hline & 20 & LAB $2^{\mathrm{b}}$ & $1 \pm 0.0$ & $1 \pm 0.0$ & $1.0 \pm 0.0^{\mathrm{x}}$ & $2.4 \pm 0.5^{\mathrm{x}}$ & $3.4 \pm 0.5^{x}$ & $4.2 \pm 0.3^{x}$ \\
\hline & 40 & None & $1 \pm 0.0$ & $1 \pm 0.0$ & $1.2 \pm 0.3^{x}$ & $2.3 \pm 0.6^{x}$ & $3.2 \pm 0.4^{x}$ & $4.2 \pm 0.4^{x}$ \\
\hline & 40 & LAB $1^{a}$ & $1 \pm 0.0$ & $1 \pm 0.0$ & $1.0 \pm 0.0^{x}$ & $2.2 \pm 0.4^{x}$ & $3.2 \pm 0.4^{x}$ & $4.2 \pm 0.3^{x}$ \\
\hline & 40 & LAB $2^{b}$ & $1 \pm 0.0$ & $1 \pm 0.0$ & $1.2 \pm 0.3^{x}$ & $2.4 \pm 0.5^{x}$ & $3.3 \pm 0.4^{x}$ & $4.2 \pm 0.2^{x}$ \\
\hline
\end{tabular}

${ }^{a}$ LAB 1, Lactobacillus sakei CTC 372; 'LAB 2, uncharacterized Lactobacillus CTC 711; *1=No off-odour, $2=$ Slight off-odour, $3=$ Little offodour, $\mathbf{4 = M o d e r a t e ~ o f f - o d o u r , ~} \mathbf{5}=$ Strong off-odour; ${ }^{\mathrm{xy}}$ Mean values in the same column are significantly different when accompanied by different superscripts $(\mathrm{P}<0.05)$. 
After 7 or 5 days of incubation at 3 or $8^{\circ} \mathrm{C}$, respectively, and at latter times, the numbers of $L$. monocytogenes recovered from broths containing $L b$. sakei CTC 372 or $L b$. CTC 711 were substancially lower than the numbers recovered from broth

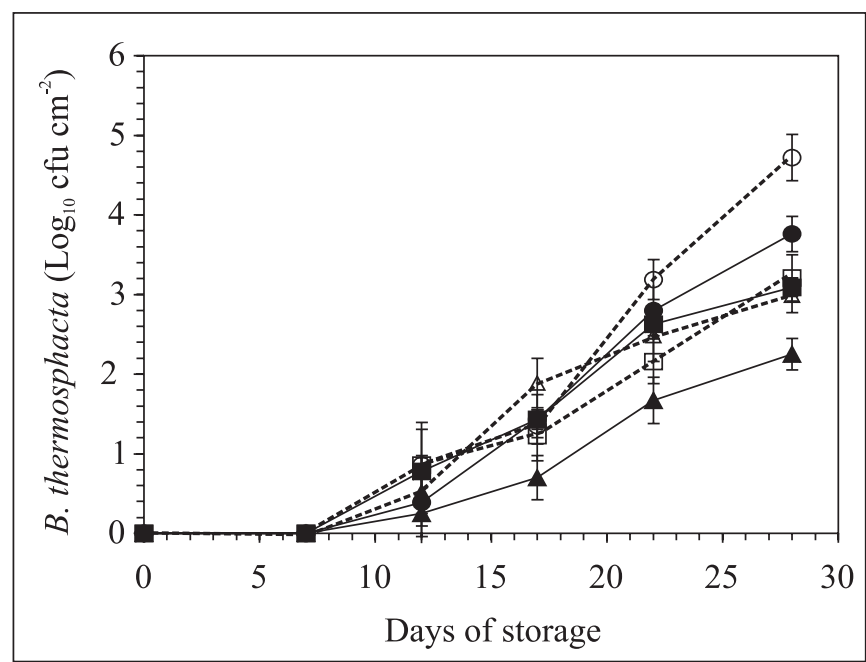

Figure 2. Numbers of Brochothrix thermosphacta recovered from beef steaks stored at $1 \pm 1^{\circ} \mathrm{C}$ under atmospheres of $70 \% \mathrm{O}_{2} /$ $20 \% \mathrm{CO}_{2} / 10 \% \mathrm{~N}_{2}$ (open symbols) or $60 \% \mathrm{O}_{2} / 40 \% \mathrm{CO}_{2}$ (closed symbols) without being inoculated (circles) or after being inoculated with Lactobacillus sakei CTC 372 (triangles) or Lactobacillus CTC 711 (squares).

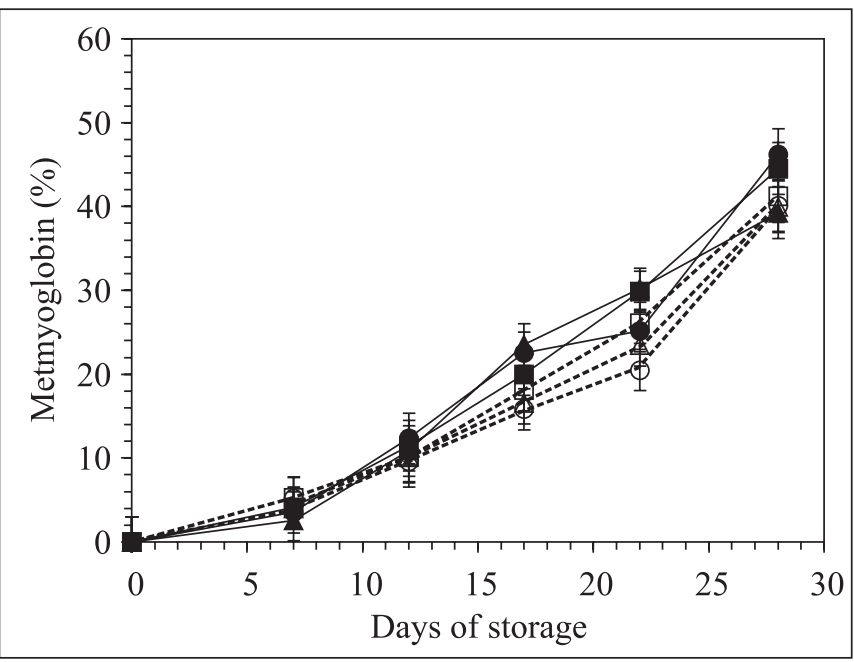

Figure 3. Metmyoglobin percentage on the surface of beef steaks stored at $1 \pm 1^{\circ} \mathrm{C}$ under atmospheres of $70 \% \mathrm{O}_{2} / 20 \% \mathrm{CO}_{2} /$ $10 \% \mathrm{~N}_{2}$ (open symbols) or $60 \% \mathrm{O}_{2} / 40 \% \mathrm{CO}_{2}$ (closed symbols) without being inoculated (circles) or after being inoculated with Lactobacillus sakei CTC 372 (triangles) or Lactobacillus CTC 711 (squares). containing L. monocytogenes only (Fig. 4). The presence of either protective strains resulted in a severe inactivation of $L$. monocytogenes after 5 days at $25^{\circ} \mathrm{C}$. The $\mathrm{pH}$ values of broths did not differ significantly ( $\mathrm{P}>0.05)$ during incubation (data not shown).

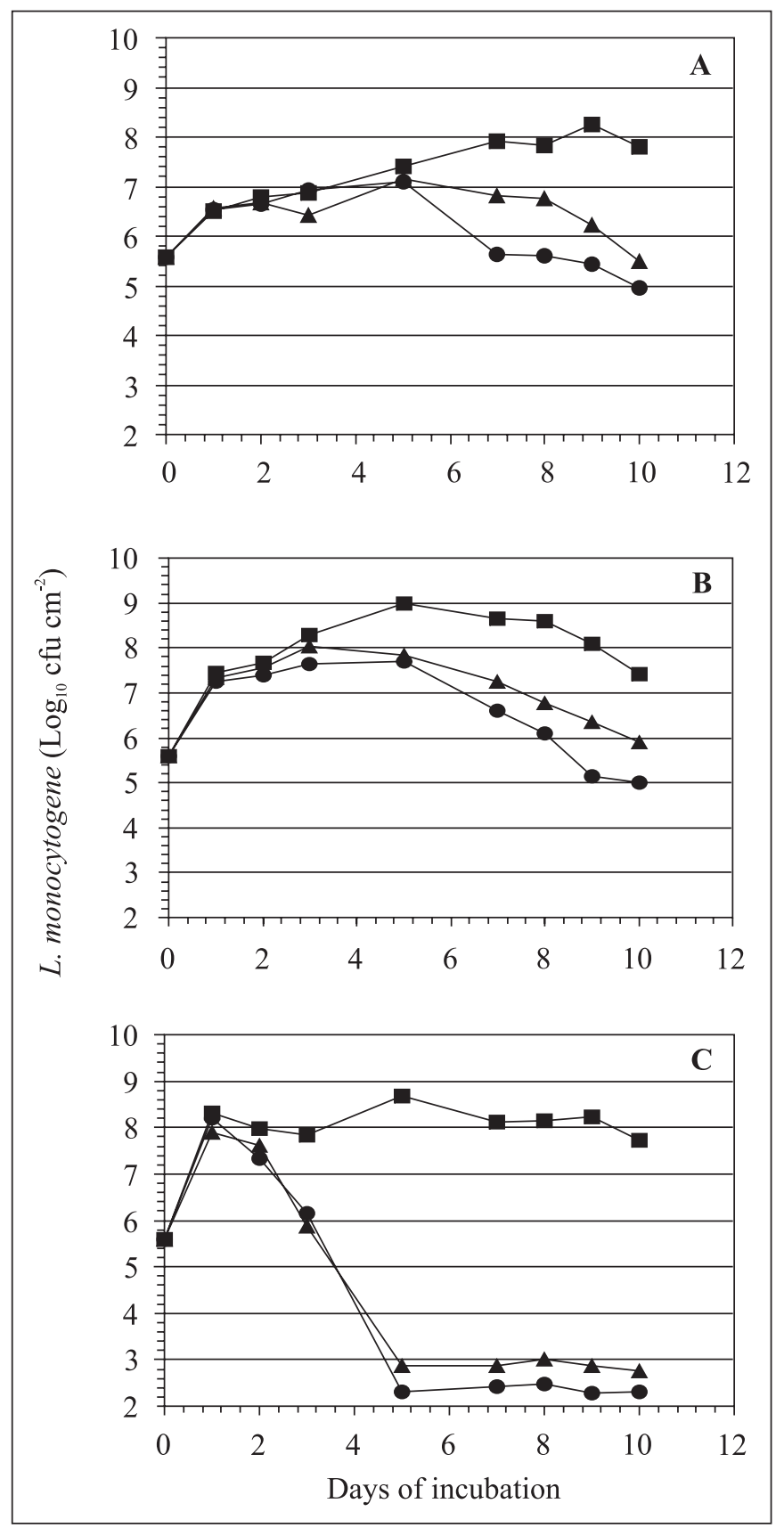

Figure 4. Effect of meat surface microbial flora without ( $\square$ ) or with Lactobacillus sakei CTC 372 (@) or Lactobacillus CTC $711(\mathbf{A})$ on the numbers of Listeria monocytogenes in broths incubated at (A) $3^{\circ} \mathrm{C}$, (B) $8^{\circ} \mathrm{C}$, or (C) $25^{\circ} \mathrm{C}$. 


\section{DISCUSSION}

Due to consumer demands and convenience at retail stores, there is great interest in developing MAP of consumer-ready cuts of meats. Spoilage bacteria tolerate high concentrations of $\mathrm{O}_{2}$ and their growth rate can be reduced by including $\mathrm{CO}_{2}$ in the gas mixture. As to the microbiological effects of $\mathrm{CO}_{2}$ atmospheres, our findings indicated that numbers of bacteria recovered from steaks packaged under $40 \% \mathrm{CO}_{2}$ atmosphere were lower than those packaged under $20 \% \mathrm{CO}_{2}$. Similar results were observed in packed steaks for 28 days of storage at $1^{\circ} \mathrm{C}$ (14). An increase of shelf-life of meat packaged in high $\mathrm{CO}_{2}$ atmospheres was expected and previously reported $(2,21)$, as was synergistic effect between $\mathrm{CO}_{2}$ and low temperature $(20,21)$.

Studies of bacteriocin-producing strains have mainly focused on the inhibition of food pathogens, but the effects of these bacteria against specific spoilage organisms is unkonwn. The inoculation of steaks with $L b$. sakei CTC 372 reduced the numbers of Pseudomonas spp. and B. thermosphacta on steaks packed under either $\mathrm{CO}_{2}$ atmosphere. After 28 days of storage, Lb. sakei CTC 372 delayed microbial growth by about 10 days for steaks packed under either $\mathrm{CO}_{2}$ atmosphere, as compared with uninoculated steaks. However, the numbers of bacteria were apparently reduced by inoculation of steaks with $L b$. CTC 711 only when steaks were packaged under $20 \% \mathrm{CO}_{2}$, with bacterial growth being delayed approximately 9 days in this case. Further studies are required to explain the ineffectivity of $L b$. CTC 711 to inhibit spoilage bacteria in steaks packed under $40 \% \mathrm{CO}_{2}$. Inhibition of spoilage bacteria on inoculated steaks can be attributed to the production of bacteriocins by either LAB strains. The combination of meat packing under MA and inoculation with bacteriocins has been shown to reduce the numbers of $B$. thermosphacta, which reached undetectable levels after 25 days of storage (50).

In this study, Pseudomonas spp. seemed to be the most vulnerable group to both protective strains of LAB. In beef packed under lower or higher concentration of $\mathrm{CO}_{2}$, Pseudomonas spp. were always minor fractions of the flora, while $B$. thermosphacta was predominant. If it is accepted that a number of $7 \log \mathrm{cfu} \mathrm{cm}^{-2}$ is the approximate point at which spoilage becomes apparent (29), the numbers of the spoilage flora recovered from uninoculated and inoculated steaks were always lower than the numbers required for spoilage.

The bacteriocinogenic LAB strains examined in this study grew and produced antimicrobial substances at refrigeration temperatures. Thus, $L b$. sakei CTC 372 or $L b$. CTC 711, originally isolated from meat products, could be useful for control of microorganisms in refrigerated meats.

With respect to meat quality characteristics, the CIE a* values, MetMb percentage and sensory odour scores during 22 days of storage can be considered similar to those of fresh meat. It has been suggested that $£ 40 \%$ MetMb on meat surface might be considered as satisfactory $(23,24,42)$, therefor, by this criterion, all the steaks should be considered satisfactory up to 22 days of storage.

With respect to off-odours, Greene and Cumuze (22) found that a TBARS value of at least $2.0 \mathrm{mg}$ malonaldehyde $/ \mathrm{kg}$ is required for perception of rancid odours. Results not shown of the present study showed that TBARS values were $<2 \mathrm{mg}$ malonaldehyde $/ \mathrm{kg}$ in steaks inoculated by either protective strain; therefore, perceptible off-odours would not be present during 3 weeks of storage, which is in accordance with the sensory analysis results.

Steaks inoculated with either protective strains had lower numbers of total psychrotrophic aerobes throughout storage (results not shown). However, the reduction in numbers of total psychrotrophic aerobes did not result in any extension of the shelf life of steaks. Those findings suggest that changes in the colour and odour of steaks packed in MA were due to oxidative processes rather than the growth of spoilage microorganisms.

The ubiquity of L. monocytogenes is well known. In food and in the environment, as in vivo infection, L. monocytogenes is exposed to many stress signals that can alter its virulence. According to Kathariou (33), stress caused by heating, freezing, dehydration, refrigeration, acids and salts, as well the exposure to disinfectants and other antimicrobial substances are of special relevance for the physiological status and virulence of this pathogen in foods.

Several studies have been performed using LAB strains to inhibit L. monocytogenes in dairy, fish and meat products $(1,15,27,39)$. Unfortunately, individual foods may also be inhibitory towards bacteriocins and thus reduce or eliminate their efficiency (17). It has been shown that the use of LAB protective strains was less efficient in foods compared to broths (7). Thus, other studies have examined their effect only in broth cultures and extrapolated results to a wider range of uses. This may be in part explained by a more thorough contact between L. monocytogenes and bacteriocin in broth than in meat, which seems to be crucial for the efficacy of the protective culture. An even distribution of LAB on the surface of product was also found to be essential for the antilisterial activity.

In the present study, we used a high inoculum in broth of $L$. monocytogenes in order to assure that the presence of high numbers of other bacteria would not give rise to inhibition because of microbial competition. The effect of the inoculated $\mathrm{LAB}$ on L. monocytogenes was by far higher at $25^{\circ} \mathrm{C}$ than at lower temperature. $L b$. sakei CTC 372 or $L b$. CTC 711 inhibited L. monocytogenes in broth by 70.24 or $64.30 \%$ respectively, after 10 days incubation. Inactivation of $L$. monocytogenes at $25^{\circ} \mathrm{C}$ can be attributed to the rapid growth and early production of bacteriocins by the bacteriocinogenic strains of LAB at this temperature. But inhibition of L. monocytogenes was also substantial at refrigeration temperatures. At $8^{\circ} \mathrm{C}$, inhibitions by $L b$. sakei CTC 372 or $L b$. CTC 711 were 32.70 or $20.72 \%$ 
respectively, after 10 days incubation. But at $3^{\circ} \mathrm{C}, \mathrm{Lb}$. sakei CTC 372 or $L b$. CTC 711 inhibited L. monocytogenes by 36.5 or $29.5 \%$ respectively. The enhancement of the antilisterial efficacy of bacteriocinogenic protective culture had already been shown in broth in previous reports $(45,46)$. Experiments were conducted at higher temperatures in order to simulate possible temperature abuse throughout the meat commercial chain. Inhibition of L. monocytogenes by $\mathrm{LAB}$ at low temperatures has been reported in broth or on meat or salmon $(8,34,44)$. That contrast with reports of the higher production of bacteriocin by LAB at low temperature than at temperatures optimal for growth (27). In accordance with the findings of this study, Luchansky et al. (36) reported that on meat inoculated with $L$. monocytogenes and $\mathrm{LAB}, L$. monocytogenes was inhibited at $25^{\circ} \mathrm{C}$ but not at $4^{\circ} \mathrm{C}$. Inoculation with protective strains did not significantly alter the $\mathrm{pH}$ of either steaks or broths (results not shown); so $\mathrm{pH}$ was not a factor in the inhibition of bacterial growth.

The $40 \% \mathrm{CO}_{2}$ atmosphere exerted a significant inhibitory effect on the growth of spoilage bacteria on steaks; and LAB protective strains $L b$. sakei CTC 372 or CTC 711 might be useful as natural preservatives for further controlling spoilage bacteria, as well as providing a hurdle to the growth of L. monocytogenes at either refrigeration or abusive temperatures. Neither the increase of $\mathrm{CO}_{2}$ in the packaging atmosphere, inoculation with LAB protective strains, nor a combination of both, resulted in any modification of meat quality characteristics.

\section{ACKNOWLEDGEMENTS}

This research was supported by project grants ALI 96-0587 and AGL 2000-1407 from the Comisión Interministerial de Ciencia y Tecnología (CICYT). D. Djenane was the recipient of a fellowship from the Agencia Española de Cooperación Internacional (A.E.C.I.). L. Martínez was the recipient of a fellowship from the Fondo Social Europeo and the Gobierno de Aragón (Grant B072/2001). The authors wish to thank Prof. Dr. F.J. Sala and Dr. M. Hugas, who kindly provided the strains of L. monocytogenes and lactic acid bacteria, respectively and Abelló Linde S.A. (Spain), which provided the packaging equipment and gas mixtures. The assistance of Mrs. Olga Isla Corral is greatly acknowledged.

\section{RESUMO}

\section{Efeito de bactérias láticas na extensâo da vida de parateleira e multiplicação de Listeria monocytogenes em fatias de carne bovina armazenadas em atmosfera rica em $\mathrm{CO}_{2}$}

Fatias de carne bovina foram inoculadas com uma de duas bactérias láticas protetoras (Lactobacillus sakei CTC 372 bacteriocinogênica e Lactobacillus CTC 711 não caracterizado) e armazenadas em atmosfera modificada $\left(20-40 \% \mathrm{CO}_{2}\right)$. A inoculação da carne com bactérias láticas protetoras inibiu a multiplicação de bactérias deteriorantes. $\mathrm{O} \mathrm{CO}_{2}$ da atmosfera e/ ou a presença de bactérias láticas não causou a formação de metmioglobina ou de odores indesejáveis. A formação de metmioglobina e as características sensoriais foram equivalentes às apresentadas por carne fresca não deteriorada e não submetida a tratamento. A multiplicação de Listeria monocytogenes em caldo foi inibida por bactérias isoladas da superfície das carnes inoculadas com as bactérias láticas. Após 7 dias a $3^{\circ} \mathrm{C}$, a contagem inicial de L. monocytogenes de $5.6 \mathrm{log}$ UFC.mL $L^{-1}$ caiu para $2.8 \log$ UFC.mL $L^{-1}$ na ausência de bactéria lática protetora. $\mathrm{A} 8^{\circ} \mathrm{C}$, as contagens de L. monocytogenes foram reduzidas em 2.5 ou $1.5 \log$ na presença de $L b$. sakei CTC 372 ou $L b$. CTC 711, respectivamente. A $25^{\circ} \mathrm{C}$, as contagens de $L$. monocytogenes no caldo contendo uma das bactérias láticas protetoras foram $5 \log$ mais baixas do que nos caldos contendo L. monocytogenes somente.

Palavras-chave: carne bovina, atmosfera modificada, conservação, bactérias láticas, deterioração, Listeria monocytogenes

\section{REFERENCES}

1. Ammor, S.; Tauveron, G.; Dufour, E.; Chevallier, I. Antibacterial activity of lactic acid bacteria against spoilage and pathogenic bacteria isolated from the same meat small-scale facility: Behaviour of pathogenic and spoilage bacteria in dual species biofilms including a bacteriocin-like-producing lactic acid bacteria. Food Control, 17 454-461, 2006.

2. Asensio, M.A.; Ordóñez, J.A.; Sanz, B. Effect of carbon dioxide and oxygen enriched atmospheres on the shelf-life of refrigerated pork packed in plastic bags. J. Food Prot., 51, 356-360, 1988.

3. Aymerich, M.T.; Hugas, M.; Monfort, J.M. Review: Bacteriocinogenic lactic acid bacteria associated with meat products. Food Sci. Technol. Int., 4, 141-158, 1998.

4. Aymerich, M.T.; Garriga, M.; Monfort, J.M.; Nes, I.; Hugas, M. Bacteriocin-producing lactobacilli in spanish-style fermented sausages: characterization of bacteriocins. Food Microbiol., 17, 33-45, 2000.

5. Barnby-Smith, F.M. Bacteriocins: applications in food preservation Tren. Food Sci. Technol., 3, 133-137, 1992.

6. Bredholt, S.; Nesbakken, T.; Holck, A. Industrial application of an antilisterial of Lactobacillus sakei as a protective culture and its effect on the sensory acceptability of cooked, sliced, vacuumpackaged meats. Int. J. Food Microbiol., 66, 191-196, 2001.

7. Budde, B.B.; Hornbaek, T.; Jacobsen, T.; Barkholt, V.; Koch, A. G. Leuconostoc carnosum 4010 has the potential as a new protective culture for vacuum-packed meats: culture isolation, bacteriocin identification, and meat application. Int. J. Food Microbiol., 83, 171-184, 2003.

8. Castellano, P.H.; Holzapfel, W.H.; Vignolo, G.M. The control of Listeria innocua and Lactobacillus sakei in broth and meat slurry with the bacteriocinogenic strain Lactobacillus casei CRL 705. Food Microbiol., 21, 291-298, 2004.

9. CIE. Recommendatios on uniform color spaces-color difference equations psychometric color terms. Commision International de l'Eclairage, Paris, 1978. Supplement $\mathrm{N}^{\mathrm{o}} 2$ to CIE Publication $\mathrm{N}^{\mathrm{o}} 15$ (E-1.3.1) 1971/(TC-1.3.). 
10. Cross, H.R.; Moen, R.; Stanfield, M.S. Training and testing of judges for sensory analysis of meat quality. Food Technol., 32(7), 48-54, 1978.

11. De Martinis, E.C.P.; Franco, B.D.G.M. Inhibition of foodborne pathogens by bacteriocin producing Leuconostoc spp. and Lactobacillus sake isolated from linguiça frescal. Rev. Microbiol., 28, 284-287, 1997.

12. Djenane, D.; Sánchez-Escalante, A.; Beltrán, J.A.; Roncalés, P. Extension of the retail display life of fresh beef packaged in modified atmosphere by varying lighting conditions. J. Food Sci., 66, 181-186, 2001.

13. Djenane, D.; Sánchez-Escalante, A.; Beltrán, J.A.; Roncalés, P. Extension of the shelf life of beef steaks packaged in a modified atmosphere by treatment with rosemary and displayed under UVfree lighting. Meat Sci., 64, 417-426, 2003a.

14. Djenane, D.; Sánchez-Escalante, A.; Beltrán, J.A.; Roncalés, P. The shelf life of beef steaks treated with DL-lactic acid and antioxidants and stored under modified atmospheres. Food Microbiol., 20, 1-7, $2003 \mathrm{~b}$.

15. Duffes, F.; Leroi, F.; Boyaval, P.; Dousset, X. Inhibition of Listeria monocytogenes by Carnobacterium spp. strains in a simulated cold smoked fish system stored at $4^{\circ} \mathrm{C}$. Int. J. Food Microbiol., 47, 33-42, 1999.

16. Farber, T.M.; Peterkin, P.I. Listeria monocytogenes: a food-borne pathogen. Microbiol. Rev., 55, 476-511, 1991.

17. Ganzle, M.G.; Weber, S.; Hammes, W.P. Effect of ecological factors on the inhibitory spectrum and activity of bacteriocins. Int. J. Food Microbiol., 46, 207-217, 1999.

18. García, De Fernando, G.D.; Nychas, G.J.E.; Peck, M.W.; Ordóñez, J.A. Growth/survival of psychrotrophic pathogens on meat packaged under modified atmospheres. Int. J. Food Microbiol., 28, 221-231, 1995.

19. Gill, C.O. The control of microbial spoilage in fresh meats. In "Advances in meat research", Vol. 2, "Meat and Poultry Microbiology", eds Pearson, A.M.; Dutson, T.R. p. 49, AVI Publishing Co., Westport, Conn, 1986.

20. Gill, C.O. The solubility of carbon dioxide in meat. Meat Sci. 22, 6571, 1988.

21. Gill, C.O.; Tan, K.H. Effect of carbon dioxide on growth of meat spoilage bacteria. Appl. Environ. Microbiol., 39, 317-319, 1980.

22. Greene, B.E.; Cumuze, T.H. Ralationship between TBA-numbers and inexperienced panelists assessments of oxidized flavor in cooked beef. J. Food Sci., 47, 52-58, 1981.

23. Greene, B.E.; Hsin, I.M.; Zipser, M.W. Retardation of oxidative color changes in raw ground beef. J. Food Sci., 36, 940-942, 1971.

24. Hood, D.E.; Riordan, E.B. Discoloration in pre-packaged beef: measurement by reflectance spectrophotometry and shopper descrimination. J. Food Technol., 8, 333-343, 1973.

25. Hugas, M.; Garriga, M.; Aymerich, T.; Monfort, J.M. Biochemical characterization of Lactobacilli from dry fermented sausages. Int. J. Food Microbiol., 18, 107-113, 1993.

26. Hugas, M.; Garriga, M.; Aymerich, T.; Monfort, J.M. Inhibition of $L$. monocytogenes in dry fermented sausages by the bacteriocinogenic Lactobacillus sake CTC 494. J. Appl. Bacteriol., 79, 322-330, 1995.

27. Hugas, M.; Pagés, F.; Garriga, M.; Monfort, J.M. Application of the bacteriocinogenic Lactobacillus sakei CTC 494 to prevent growth of L. monocytogenes in fresh and cooked meat products packed with different atmospheres. Food Microbiol., 15, 639-650, 1998.

28. Hugas, M.; Garriga, M.; Pascual, M.; Aymerich, M.T.; Monfort, J.M. Enhancement of sakacin $\mathrm{K}$ activity against Listeria monocytogenes in fermented sausages with pepper or manganese as ingredients. Food Microbiol., 19, 519-528, 2002.

29. Hunt, M.C.; Mancini, R.A.; Hachmeister, K.A.; Kropf, D.H.; Merriman, M.; Delduca, G.; Milliken, G. Carbon monoxide in modified atmosphere packaging affects color, shelf-life, and microorganisms of beef steaks and ground beef. J. Food Sci., 69, 45-52, 2004.

30. ICMSF. International Commission of Microbiological Specifications for Foods. Microorganisms in foods. Vol. 1. Their significance and methods of enumeration. (Elliott, R.P.; Clark, D.S.; Lewis, K.H.; Lundbeck, H.; Olson, J.C.Jr.; Simonsen, B. (eds). Toronto, 1983. University of Toronto Press.
31. Jamuna, M.; Babusha, S.T.; Jeevaratnam, K. Inhibitory efficacy of nisin and bacteriocins from Lactobacillus isolates against food spoilage and pathogenic organisms in model and food systems. Food Microbiol., 22, 449-454, 2005.

32. Jay, J.M. "Modern Food Microbiology." $4^{\text {th }}$ eds. Chapman \& Hall, New York, 1992.

33. Kathariou, S. Listeria monocytogenes virulence and pathogenicity, a food safety perspective. J. Food Prot., 65, 1811-1829, 2002.

34. Katla, T.; Møretrø, T.; Aasen, I.M.; Holck, A.; Axelsson, L.; Naterstad, $\mathrm{K}$. Inhibition of $L$. monocytogenes in cold smoked salmon by addition of sakacin P and/or live Lactobacillus sakei cultures. Food Microbiol., 18, 431-439, 2001.

35. Ledward, D.A. Metmyoglobin formation in beef stored in carbon dioxide enriched and oxygen depleted atmospheres. J. Food Sci., 35, 33-37, 1970.

36. Luchansky, J.B.; Glass, K.A.; Harsono, K.D.; Degnan, A.; Faith, N.G.; Cauvin, B. Genomic analysis of Pediococcus starter cultures to control L. monocytogenes in turkey summer sausage. Appl. Environ. Microbiol., 58, 3053-3059, 1992.

37. Martínez, L.; Djenane, D.; Cilla, I.; Beltrán, J.A., Roncalés, P. Effect of different concentrations of carbon dioxide and low concentration of carbon monoxide on the shelf-life of fresh pork sausages packaged in modified atmosphere. Meat Sci., 71, 563-570, 2005.

38. Marth, E.H. Extended shelf life refrigerated foods. Food Technol., 52(2), 57-62, 1998.

39. Mcauliffe, O.; Hill, C.; Ross, R.P. Inhibition of Listeria monocytogenes in cottage cheese manufactured with a lacticin 3147-producing starter culture. J. Appl. Microbiol., 86, 251-256, 1999.

40. Pfalzgraf, A.; Frigg M.; Steinhart, H. Alpha tocopherol contents and lipid oxidation in pork muscle and adipose tissue during storage. $J$. Agric. Food Chem., 43, 1339-1342, 1995.

41. Pleasants, A.B.; Soboleva, T.K.; Dykes, A.; Jones, R.J.; Filippov, A.E. Modelling of the growth of populations of Listeria monocytogenes and a bacteriocin-producing strain of Lactobacillus in pure and mixed cultures. Food Microbiol., 18, 605-615, 2001.

42. Renerre, M.; Mazuel, J.P. Relation entre méthodes de mésure instrumentales et sensorielles de la couleur de la viande. Sci. Alim., 5, 541-557, 1985.

43. Sanchez-Escalante, A.; Djenane, D.; Torrescano, G.; Beltrán, J.A.; Roncalés, P. Antioxidant action of borage, rosemary, oregano and ascorbic acid in beef patties packaged in modified atmosphere. $J$. Food Sci., 68(1), 339-344, 2003.

44. Schillinger, U.; Lücke, F.K. Lactic acid bacteria as protective cultures in meat products. Fleischwirtsch, 70, 1296-1299, 1990.

45. Schillinger, U.; Lücke, F.K. Behaviour of L. monocytogenes in meat and its control by a bacteriocin-producing strain of Lactobacillus sake. J. Appl. Bacteriol., 70, 473-478, 1991.

46. Schillinger, U.; Chung, H.S.; Keppler, K.; Holzapfel, W.H. Use of bacteriocinogenic lactic acid bacteria to inhibit spontaneous nisinresistant mutants of Listeria monocytoenes Scott A. J. Appl. Microbiol., 85, 657-663, 1998.

47. SPSS. SPSS for Windows, 6.1.2. Chicago. SPSS Inc. 1995.

48. Stewart, M.R.; Zipser, M.W.; Watts, B.M. The use of reflectance spectrophotometry for the assay of raw meat pigments. J. Food Sci., 30, 464-469, 1965.

49. Stiles, M.E. Biopreservation by lactic acid bacteria. Ant. van Leeuwen., 70, 331-345, 1996.

50. Tu, L.; Mustapha, A. Reduction of Brochothrix thermosphacta and Salmonella serotype Typhimurium on vacuum packaged fresh beef treated with nisin and nisin combined with EDTA. J. Food Sci., 67, 302-306, 2002.

51. Wimpfheimer, L.; Altman, N.S.; Hotchkiss, J.H. Growth of $L$. monocytogenes Scott A, serotype 4 and competitive spoilage organisms in raw chicken packaged under modified atmospheres and in air. Int. J. Food Microbiol., 11, 205-214, 1990. 